\title{
Learning and Teaching in Innovation: why it is important for education in 21st century
}

\author{
Helena Kovacs*
}

The purpose of this article is to understand the state of play in today's research into the field of teacher learning and teacher professional development, as well as to make a connection with the need for change in how education is implemented in schools of 21st century. The study portrays the accelerated learning curve for teachers in innovative learning environments which as such demand collaboration, experimentation and questioning of one's own practice. The conclusions point out the need for spreading the examples of successful pedagogical and technological innovations and further stimulating teacher learning in order to get better results for schools, pupils and societies in the future.

Keywords: teacher learning, teacher professional development, innovation, educational change, 21st century skills

\section{Introduction}

The title makes a staggering impression and alludes to a state of urgency that is oriented towards innovation. Yet, the words were purposefully selected and composed bearing in mind the state of the traditional education and its tendency towards status quo. Thus, it is in the aftermath of dreadful happenings in the world today that makes educational researchers think about the purpose and the potential of education that has been unharvested or, what is even more frightening, used to wrong outcomes (UNESCO, 2015). And while education cannot and should not be a sole element in causing or solving the multiple social problems in the world today, it most definitely can play its part and take its role in changing the minds of future generations.

From the standpoint at which it is believed that education has the ethical duty to support a positive change in society, this paper intents to create a debate about the state of urgency on how we approach education today. Additional to this, the role of the teacher is seen as one of the most crucial - the skilfulness of manipulating and leading the learning process (Biesta, 2012) and the astonishing importance of teacher-student relationship and feedback (Hattie, 2013) are just two of the core predicaments that can make a difference in the classroom. It has been identified at several levels that teachers are "the most important single factor determining the quality and effectiveness of education" (Issues paper, EDiTE conference, 2014). Henceforth, this article shall examine two elements, the potential of education and the significance of teachers' role, in a joint manner to develop a greater understanding of their interconnectedness, mutual dependence and significance to educational research today. In order to narrow down and sharpen the focus, the article intends to look into the innovative educational practices as the ways of exploiting the potential of education, as well as the ways teachers in such environments exceed themselves and their traditional images by engaging in accelerated learning and development.

* A Horizon2020 Marie Sklodowksa Curie program által támogatott EDiTE projekt (European Doctorate in Teacher Education) fiatal doktorandusz kutatója az ELTE-n. E-mail: helena.kovacs@ppk.elte.hu 
Purpose and the question

As an initial contribution to the framework research theme The Learning Teacher, this article shall look into and explore the contemporary literature and debates related to teacher professional learning and development, as well as the state of innovation in education. In particular, by contextualising innovative instructional provisions as the main setting for teaching, the question about the benefits for teachers in terms of their further development will be the central theme here. In order to elevate the discussion and connect it to a somewhat higher course of educational discourse, the article intends to answer the following question:

\section{Why is it important to obtain more research about teacher learning in innovative learning environments?}

Accordingly, the article's essence will be predominantly theoretical relying on a number of readings collected within the related fields of study. The paper will first try to capture the nature of teacher learning as a core con ceptual factor, particularly by examining the importance of learning for teachers and teaching profession in general, as well as exploring the means and ends of acquiring professional knowledge. Once the general provisions on teacher learning have been laid out, the article will portray the specific context of innovative learning environments and briefly describe what innovation in education means. In the final bit, the initial main question will be answered by looking into what is known in relation to the critique of educational provisions today, thus how these issues connect to teacher learning in innovative learning environments. At its very end, conclusion shall be given, as well as several points that can potentially open the discussion further.

\section{Teachers teach - teachers learn}

Learning is a part of everyone's life, personally and professionally, thus it is inevitable to imagine that learning happens all the time, regardless whether intentionally or unconsciously (Coffield, 2000; Illeris, 2009). In educational science, and particularly in the research field of teacher learning, understanding the concept of learning is of utmost importance. Darling-Hammond (2015) notes that not even half of what is known in the field of learning is used in today's schools across the globe. This article reiterates the importance of learning within the teaching profession by approaching it from these three perspectives:

1. Learning (opportunities) created by and among teachers

2. Learning (patterns and discourses) of students

3. Learning as the environment of schools as institutions

Willingly or not, teachers learn about the profession and the world around them through interactions, consultations, experimentations, reflections and solving problems, but also by observing other professionals in schools and outside (Eraut, 2007; Bakkens et al.., 2010). Illeris (2009; 2015) calls it an interaction between the learner and the environment, which once absorbed and connected to prior learning, produces a new learning outcome. This new learning can transpose into a cognitive, emotional and/or behavioural change. As Jarvis (2009) reminds, learning is a process involving a whole person - body and mind - thus affecting person's biography. Today, more than ever, teachers need to be quick in acquiring new knowledge and skills in order to provide effective learning in the classroom (Darling-Hammond, 1998; 2015). Therefore, teacher learning in the $21^{\text {st }}$ century is no longer an option but a sort of a moral duty that comes with the profession (Kwo, 2010) and to be able to conduct their jobs, teachers need to know how to work with others, with different types of knowledge, technology and information and how to work with and in society (European Commission, NN). 
Teacher's ability to perform automatically connects and reflects on student learning (Hattie, 2013). Their capacity to successfully and effectively deliver a learning is (still) seen as the main denominator of value. In such a paradigm, teachers are inevitably tied up to student learning outcomes, which in a number of cases are assessed through standardised national and international tests that focus on only few specific skills and knowledge. By analysing this, Martin-Brown (2015) argues that teachers are no better than factory workers that are directed to make a standardised product and are fearful to experiment and innovate as the new output might not fit the uniformed, comparable and regulated measurement. Yet, even with such restrictions, teacher's job is to learn and understand patterns and discourses of student effective learning. Darling-Hammond (2015) reminds us that there are scores of available literature on learning and unfortunately most of it is not used in improving schools of the $21^{\text {st }}$ century. The patterns currently used in majority of schools are those that have been designed for the needs of the industrial era, and not for the knowledge era (Darling-Hammond 2015; Martin-Brown 2015). Thus, the term student effective learning carries a mixed message fluctuating between a standardised outcome in terms of literacy and numeracy, and a set of soft skills such as critical-thinking, creativeness and aptitude for continuous learning, which are rather difficult to measure and compare. This said, student learning is a must for teacher's teaching, and teaching in the $21^{\text {st }}$ century requires teacher learning more than ever.

Finally, in addressing the third aspect of the learning given above, schools are human-made contexts where learning in implied. Schools are also teachers' workplaces, thus their teaching and some of their learning happens in schools. Yet schools offer specific types of learning, the one that has been selected and instructed by the formal education system. Biesta (2012) makes a point that through education students "learn something, they learn this for particular purposes, and [that] they learn this from someone" $(2012,36)$. This makes schools a controlled learning environment, but as noted above - this controlled learning environment is also teachers' very own working place. Thus, investigating the change of schools in the $21^{1 \text { st }}$ century directly implies following the patterns of adaptation and learning among the teachers.

Hence, these three aspects are important and shall be ever-present when discussing teacher learning. Focus ing only on one of these aspects without at least remotely considering the others would feel incomplete and incoherent. Consequently, the article shall continue to analyse the qualities of teacher learning with a constant reminder of the three aspects portrayed above.

\section{Teacher learning: professional knowledge in the workplace}

In most of the professions, including teaching, there is an important dilemma that opens up when approaching professional learning and professional knowledge. It was in the early 1980s when Schön (1983) evoked a discus sion on professional learning and what he described as the crisis of confidence. He stated the following:

"We look to professionals for the definition and solution of our problems, and it is through them that we strive for social progress (...) But although we are wholly dependent on them, there are increasing signs of a crisis of confidence in the professionals" (Schön, 1983, 4).

Yet, beyond this, the author argues that this assumption of professionals being the problem-solvers is a dangerous avenue. In fact, professionals do not always have the best solutions to the problems, and as Schön (1983) noted, the crisis of confidence in professional knowledge comes in a form of anxiety that appears particularly in the service and public sector workers that experience strong societal expectation of high performance. This creates a "mismatch of traditional patterns of practice and knowledge to features of the practice situation - com- 
plexity, uncertainty, instability, uniqueness and value conflict - of whose importance they are becoming increas ingly aware" (Schön, 1983, 18).

As a conclusion, professional knowledge should not, cannot and does not rely on the general theoretical knowledge of the issues the professionals are facing in their professional experience. Instead, knowledge should be widely considered as embedded in experiences that the professionals go through over their entire engagements (Schön, 1983). This kindles another concept called the reflective turn which suggests an "alternative approach to research with focus on subtle and implicit artistry of professional practice" (Kwo, 2010, 314), an element that will be explored later.

To complement the above, according to Eraut (2007) there are few very distinct characteristics of professional knowledge that makes it very hard to systematically evaluate and measure. These characteristics suggest that professional knowledge has:

1. A large and important tacit dimension

2. A significant implicit part to it making people unaware of the processes and outcomes of learning

3. A sense of complexity which is needed for dealing with complex tasks.

These features create significant considerations when researching what and how learning occurs in the workplace, as well in understanding what distinct factors affect learning efforts. Eraut (2007) reminds that by looking into the form of delivery, most of the learning within the workplace is informal type of learning "triggered by (1) consultation and collaboration within the working group, (2) consultation outside the working group and (3) the challenge of the work itself" (Eraut, 2007, 408). Although there might be a large difference when approaching various workplaces, from highly innovative to those very routine, it can be argued here that Eraut's idea of learning is applicable to all working places, although with different intensity, frequency and depth. This includes classrooms and schools.

The above statement only proves that professional knowledge is deeply and inseparably immersed with the workplace, thus largely stems from learning acquired through the job itself. Likewise, Cochran-Smith and Demers (2010) suggest that learning to teach is not a set of lessons that happens at a particular point in time and has a determined finish, but is rather an ongoing process that occurs across time and throughout one's career. However, in order to keep things simple, Baijaard and his associates (2007) suggested that learning of teachers can be divided into initial teacher education - the formal education and training that a student acquires in order to enter the profession - and continuous professional development - a set of formal, semi-formal and informal activities that practicing teacher undertakes in the lifespan of their careers. Arguably, another type of learning could be added to the idea of "becoming a teacher" considering Illeris' learning triangle $(2009 ; 2015)$ and Bandura's learning by modelling theory. This is the early learning about the profession, which happens in early childhood and adolescence. Young generations perceive specific trades of teacher(s) which makes them implicitly learn about "being" a teacher, of what are the benefits and what are the negatives of becoming one.

\section{Teacher learning: the how's and the what's}

In their thorough mixed-method research of teachers and their learning, Bakkens and her colleagues (2010) have set their aim to make a classification of teacher learning by the type of activity, as well as by the type of outcome. They have noticed that even if teachers engage in the same visible activity the learning outcome as well as their thinking processes might, and quite often will, result differently. Furthermore, in order to have meaningful outcomes, teachers need to be engaged in what the general academic literature recognises as active and self-regulated learning, where they have an active role in learning with the potential of controlling what they 
learn and how the process takes place. This gives control over regulating their own cognition, motivation and behaviour, as well as creating favourable environment for their learning (Bakkens et al., 2010). Nonetheless, it has also been recognised that "[i]n principle every activity can lead to a change in knowledge, beliefs or prac tices, even when a teacher did not have the intention to learn from that activity" (Bakkens et al., 2010, 536).

Within their study, Bakkens et al. (2010) propose six categories of learning activities and four categories of learning outcomes. The learning activities describe ways in which teachers learn, and this includes:

- Experimenting

- Considering own practice

- Experiencing friction

- Struggling not to revert to old ways

- Getting ideas from others

- Avoiding learning.

The research showed, however, that not all activities occurred with the same frequency. Two of the most common that account for around $2 / 3$ of the situations were considering own practice and experimenting. Other two categories that were also relatively highly represented among teachers were getting ideas from others and experiencing friction, while avoiding learning was the least frequent. Even though the research team has not explicitly mentioned, it is quite possible to have a combination of activities at one time. It is not unlikely that while getting ideas from others one can also consider their own practice. These conclusions on learning activities came after examining a specific school setting that underwent a national innovation reform, and while it is important to understand that Bakkens et al. study focuses on teacher learning under the auspices of an innovation intervention, some of the ideas about teacher learning can be applicable even in the routine-based educational provisions.

This said, Tynjälä (in Bakkens et al., 2010) offers a slightly broader set of learning endeavours in order to encompass a greater sense of learning at work. Tynjälä suggests that learning can happen in the following occasions:

1. By doing the job itself

2. Through co-operation and interaction with colleagues

3. Through working with clients

4. By tackling challenges and new tasks

5. By reflecting on and evaluating one's work experiences

6. Through formal education and training

7. Through extra-work context.

These aspects of work-based learning are easily observed in a school setting and among teachers. It is worthwhile to mention that the school setting is also characterised by a strong communal sentiment that brings out multiple communities of practices, as proposed by Lave and Wenger (1991). This suggests that there are knowledge and skills that are situated and cannot be learnt from a theoretical framework.

The above section provides a good illustration on how teachers learn in their workplaces and in schools as learning environments, yet another important perspective of learning is the question concerning what teachers learn. An attempt to reveal this aspect was done by Bakkens et al. (2010) study in respect of changes that happen after observing patterns of learning. Thus, the research team established four categories of learning outcomes, namely: 
- Changes in knowledge and beliefs (including awareness, confirmed ideas and new ideas)

- Intentions for practice (including intentions to try new practices, intentions to continue new practices and intentions to continue current/old practices)

- Changes in practices (including new practices and getting back to old practices)

- Changes in emotions (including positive emotions, negative emotions and surprises).

The research results showed that learning activities and learning outcomes are connected in multiple ways, indicating that it is very rare that one particular activity will cause one particular outcome. Rather, it is an interplay based on the individual teacher aptitudes and prior learning, as well as external factors, that are all combined when it comes to teacher learning.

While Bakkens et al. specifically looked at the context of educational innovation, Kwo (2010) suggests that rather than restricting learning space for teachers to schools and institutional environments, teacher learning should be observed in a wider global (and virtual) space. She notes that "[t]he locations of teacher learning, as captured from the contributions by various authors, reveal the challenges of established routines and systems, multiple tracks of inherently conflicting discourses, and authoritatively imposing theories and assumptions that can threaten to reduce teachers' learning space to formal setting in structured modes" (Kwo, 2010, 322).

Kwo reiterates the idea and agrees with Cochran-Smith and Demers (2010) that teacher learning does not come in a form of a set day-to-day activity, but is rather a process of teachers' engagement in taking challenges and opportunities "with thoughtful reconnections within their inner worlds" (Kwo, 2010, 325). Ora Kwo reminds of the essential role of language in teacher learning, as the tool that can make explicit that what is implicit and hard to observe. Therefore, "[t]his observation further challenges the conventional mode of training for teacher development that may have disregarded the latent power of teachers to learn, the significance of the struggles, and the deep meaning of support needed" (Kwo, 2010, 325). Essentially, in her closing chapter of Teacher as Learners, the author asks two valid questions (Kwo, 2010, 326):

1. Why do some teachers persevere as learners, whereas many other teachers merely engage in routinized practice?

2. What are the motivations for and consequences of committed learning?

The answers to these questions certainly do not come easy nor straightforward, and while there is a notion of difficulty in keeping a pace to learn with a full-time teaching job, there are intrinsic and extrinsic forces that can be mentioned. Greene (in Kwo, 2010) offers an essentialist philosophical approach suggesting that a teacher learns in order to re-interpret reality and gain readiness to enter a form of liveliness, therefore it is a way in which teachers can understand life and understand themselves. Likewise, teachers who persist in being learners as well as those who do not, might behave accordingly by following a set of similar reasons. For instance, there is a common belief that teachers are supposed to be experts in learning (Bakkens et al., 2010) which might act both as a stimulus and as an impediment to teachers to learn. In case of hindrance to learning, the ego and superiority can act contrary to one's drive to professionally develop. On the opposite side, a teacher might feel a moral obligation to continuous learning exactly because of being at the forefront of learning. As Kwo perfectly puts it:

"Sustainable learning is a form of engaged living as moral beings. It is only when teachers can identify themselves as moral beings, concerned with questioning and making choices that they can create their own moral lives and arouse their students to learn to break with what can be too easily taken for granted" (Kwo, 2010, 332) 
This suggests that teachers who embrace learning as part of their job gain access to fuller life as professionals.

\section{Setting the context: the innovative school environment}

Everything about schools indicates that they are learning environments. Next to being the most systematic vehicles for student learning, they are also environments of teacher professional learning and development. Nevertheless, teacher learning in traditional school setting can be seen as unimportant and meagre, exploited mainly at the novice level. Innovative schools make a strong imposition on teacher learning, demanding from the entire school collective to switch to a dynamic mode. Thus, the context of the overall research within the strand of the Learning Teacher framework, this article included, will be the innovative school.

\section{Innovation: the basics}

In order to grasp the concept of innovation, it is necessary to diverge from the field of education, teaching and learning, and dip into the fields where innovation has already left a greater impact, such as science, technology and industry. Typically, these three fields are best known for their innovative aptitude, perhaps also due to the fact that innovation is sometimes closely connected to invention, research and economic development. Thus, understanding what innovation is, how and why it became a paramount for great majority of industry would help in grasping its emerging meaning in the field of education.

Canadian researcher Benoît Godin looked at defining innovation from both historical and contemporary perspective. In his extensive research that resulted in a vast number of articles and working papers, crowned by a publication Innovation Contested - The Idea of Innovation over the Centuries (2015), Godin comments that innovation has become an important, inseparable trade of modern life, even though it was heavily contested just several decades ago. As a concept, innovation goes back to antiquity, yet it has not always enjoyed such an attractive high-placed position (Godin, 2014, 6). With the arrival of the Puritans, the term was widely used as a tool against the Church of England which made the concept become "associated with political revolutions and, incidentally, with violence" $(2014,7)$. The so-called "(social) innovators" were those socialists, social reformers and deviant citizens that were strongly against the system of social and economic order at the beginning of 1800s, and as such had a strong derogatory connotation.

After the French Revolution the term innovation gained a more respectable connotation and particularly in the last 50 years has been turned into an ideology. Without an exception, innovation today is highly valued everywhere, connecting to economy as a useful vehicle of change, and to culture in form of creativity - especially in relation to the originality of idea (Godin, 2014). Thus, it was only after the $19^{\text {th }}$ century when innovation got defined as a "change to the established order, a change that is intentional, a change that brings radically or revolutionary transformed society" (Godin, 2015). Thereafter, the term innovation has resurrected as one of the optimal states of any organisation, including the organisation of the entire state.

Aiming to define the term, O'Sullivan (2008) started with The New Oxford Dictionary of English which says that innovation is "making changes to something established by introducing something new" (O'Sullivan, 2008, 4; O'Sullivan, 2007, 6). He gradually worked towards adding elements and addendums that were important to give innovation a well definable boundary, resulting with the following: 
"Innovation is the process of making changes, large and small, radical and incremental, to products, processes, and services that results in the introduction of something new for the organisation that adds value to customers and contributes to the knowledge store of the organisation" (O'Sullivan, 2008, 5).

Thus, to do innovation is to simply apply a set of tools and techniques that make this change happen. As such, this definition can be used in multiple settings, including education, especially if considering a broadening the definition of the word consumer.

Finally, in defining innovation in relation to imitation, Godin (2016) makes an argument on the contrasts between innovation and imitation. In his conceptualisation, innovation which is either technological and economical, or cultural, seems to have all the traits opposite to imitation. Innovation today works within the frameworks of originality and development, and Godin (2016) notes that this was not the same at the beginning of the $20^{\text {th }}$ century. While for Godin innovation as a distinct concept of the modern society categorically is not and cannot be the same as imitation, there is no academic accord in this regard. For instance, another great name in theories of innovation, Everett Rogers claims that "an innovation is an idea, practice, or project that is perceived as new by an individual or other unit of adoption" (Rogers, 2003, 12). This indicates, first of all, that the innovative object (idea, practice or project) doesn't need to be original but rather perceived as new, and secondly, the notion of the object being adopted indicates that something has already been created rather than being creatively developed. Brier (2013) in his world-famous video and brief article also argues that innovation is one of those dots that among all the other familiar dots has not been seen before, or has been ignored, or has been forgotten, pertaining the idea that innovations are basically in front of our eyes and it is only the matter of our capacity to see and recognise them. Nevertheless, even Rogers agrees that most of the people are imitators and followers, and only a very small percentage of the population are innovators (in Godin, 2016). Therefore, this makes the debate on the value of creativity and originality in innovation, as well as a demand of exceptionality, and openended arena with no definite ends. These discussions are appropriate since they extend to the field of education asking the same generic questions on historical essence of educational innovation, the harmful frequent use of the term, and the core of the meaning as it relates to ingenuity, creativity and contextual embeddedness.

\section{Innovation in education: a "shy" phenomenon}

In approaching the topic of innovation in education, there are few important considerations to bear in mind. In literature, the topic of innovation in education is approached at least from two significant perspectives; first, there is the aspect of penetration of innovation and innovative concepts to education, i.e. how innovations from other sectors or within the education sector make things better and contribute to the outcomes, as well as how innovations change and mould education. An example of this is the insertion of technology (e.g. the Internet) into education. On the other end, innovation is looked from the side of educational output, especially how education can support innovation, what needs to be changed within the education system and within how new generations are taught in order to get more innovative students and graduates, as well as more innovative teachers and lecturers. Examples are usually connected with measuring innovation as an output of education - e.g. student start-ups, entrepreneurial ideas, development of incubators, social entrepreneurship, etc.

Next to this, literature indicates that innovation in education as a topic is strongly present at the level of higher education, while at the lower levels and in adult education this topic resonates to a much lesser extent. The reasons for this lie in the natural connection between the two - higher education is the level where research 
and science are at its prime, they are frequently associated with new discoveries, development and growth, which are inseparable elements of innovation as such.

Even with this said, a search for illustrations of today's innovative schools leads to a plentiful and rich source of practical examples worldwide. Such are, for instance, platforms like InnoveEdu and EdSurge, as well as the Finnish hundrED that is in the middle of implementation. Such platforms offer a selection of practical examples of innovative schools by following a set of criteria. Interestingly, these and many other similar online sources, are in accord with the available literature on definitions for the progressive innovative schools. Some of the common factors include the following features:

- Development of 21st century skills

- Personalised and individualised learning

- Hands-on and experiential learning

- Community based learning that looks into the locality and the world at large

- New set of credentials (measurements) that encompass a variety of learning experiences

In fact, one of the most common characteristic of innovative schools found across different sources is the ability to offer the acquisition of the skills for the $21^{\text {st }}$ century. These are most commonly defined as the 4Cs: communication, collaboration, creativity and critical thinking (taken from EdSurge). Other sources like the Organisation for Economic Cooperation and Development (OECD), while referring to the $21^{\text {st }}$ century skills, describe these skills using a different set of competences such as abilities to achieve goals (perseverance, self-control, enthusiasm), ability to work with others (cordiality, respect, care) and ability to manage emotions (calmness, optimism, confidence).

Furthermore, in the recent decades, innovations have started to appear in a range of national education systems in countries across the globe. In such cases, innovation is not only seen as an important outcome of education, but as the driving force too. For instance, the government of New Zealand has carried out a thorough as sessment and transformation of its entire education system, including the matters of governance, curriculum, qualifications, teaching and learning, as well as assessment. This systematic evaluation took into consideration all available data on New Zealand's educational performance alongside with all available knowledge on how to emerge into a system that suits the requirements of $21^{\text {st }}$ century (Government of New Zealand, n.d.). Inevitably, when approaching such exhaustive changes, countries innovate in modifying old traditions of educational provisions, especially at the pre-tertiary level, enabling professionals to strive for excellence. Thus, it could be argued that the innovative education systems tend to rethink the purpose of education by understanding the needs of the society at large, integrate the latest innovations in education (both instructional and technological), and actively work towards developing skills, knowledge and values necessary for the future (UNESCO, 2015).

In practice, innovations in pre-tertiary education mainly reflect two aspects: 1) innovations in teaching methodologies - methods used for teaching and learning, also known as instructional innovations or innovative teaching practices, and 2) technological innovations - infiltration, development and use of information and communication technologies (ICT) and online educational resources (OER). Both are seen to support innovativeness of a school, promote non-traditional learning schemes and induce teacher professional development and learning. 


\section{Instructional innovations: the pedagogy for a different outcome}

Instructional innovations are not a new concept in education. In 1985, Kozma presented his grounded theory of instructional innovation in higher education by firstly reflecting on programmes that promoted innovative pedagogies and methodologies such as individualised, computer-based, inquiry-based approaches, as well as the use of audio-visual innovations. His comprehensive literature review of the existing framework that was used to examine and organise innovations in (higher) education included the following approaches:

1. The complex organisation framework

2. The conflict framework

3. The diffusion model / framework

4. The planned change framework

A closer look at these frameworks suggest their applicability to any (learning) context that is evolving from routine-based to an innovative one. In the first approach, innovation comes as a decision taken by the people with authority in situations of external pressure for change. The innovation process invokes organisational complexity, yet remains to be formally and centrally implemented. The conflict framework, as the name suggest, involves clash between groups and / or between individuals that results in a change of the social structure or the working / learning environment. In the third approach Kozma notes "innovation is a given (...) [and] the introduction of something new into a system creates its own press for change" (Kozma, 1985, 302-303). In this model, the innovation will diffuse according to the speed of the adopter and the complexity and compatibility of innov ation itself. Finally, the framework of the planned change incorporates the intrinsic interpersonal process connected to the need for self-actualisation, which is usually connected to high quality communication, trust and participation in decision-making at different levels (Kozma, 1985).

Yet, the critique noted by the author himself suggests that innovation needs rethinking. His grounded theory has for its goal "to build understanding of basic social processes, the pervasive, patterned phenomena in the organisation of social behaviours that occur over time and go regardless of place" (Kozma, 1985, 307).

Yet, returning to the topic of innovative teaching practices, a range of new approaches and methods surfaced in the mid of $20^{\text {th }}$ century. It is not very clear when the first pedagogical innovation came about, but a possible pioneer in proposing novel methods in educating children might have been Maria Montessori at the end of 1800s, followed by Waldorf education (Steiner education) at the beginning of the 1900s. Both approaches included a child-centred and hands-on practice that teachers of that time were not very acquainted with. Even today, student-centred pedagogy is unfamiliar for many teachers across the globe. Also, it is worthwhile mentioning that, similar to Montessori, many innovative approaches developed through supporting the learning of pupils who are differently-abled, either in special needs educational environments, inclusive education or education of the gifted children. Today, a large body of educational theory recognises that classroom structures are not homogenous - thus every student is considered as a unique personality with an aptitude for learning. Henceforth, instruc tional innovations of the recent date all consider a learner-centred approach with a pedagogical ideal that every child has the potential for development.

Innovative pedagogical approaches can be classified in different ways considering their joint characteristics. For instance, Johnson and his colleagues (2000) have summoned the most influential methods that promoted cooperative learning. Cooperative learning is a joint term for methodologies that magnify students' intentions of working together in order to accomplish a shared learning goal. An important feature of collaborative learning is that the goals can be only achieved if each pupil does their share of the task (Johnson et al., 2000). 
Recently, other instructional pedagogical approaches gained prominence for their abilities and intention to tackling a spectrum of issues and addressing students' learning needs as well as educational and social challenges. Such are project-based learning (also abbreviated as PBL) and deeper learning that both came from the realms of industry and ever since have been providing evidence of effective teaching and learning with desirable outcomes in terms of students' knowledge, skills and attitudes (CELL, 2009; Ellis et al., 2011; Halvorsen et al., 2014; Mergendoller and Thomas, n.d.). Pedagogical inventiveness and innovation has almost become an integral part of teacher's job in some countries and contexts and further exploration of such practices has just begun to gain ground.

\section{Technological innovations: Still not fully there}

The debate on ICT innovations in education extends to far reaches; Graham Brown-Martin (2014) claims that the disruption that everyone expected to happen with investing in technology in education, did not really take place. He states that from all the contexts he has explored over the years of his investigations, introduction of technology such as computers and mobile devices (laptops, tablets and smartphones) as well as with "virtualisation" of education through Massive Open Online Courses (MOOCs) and other digital distant learning, did not really provide input to two expected changes. One is the ways the classes are taught, and the other and more essential, what the education aims in the first place, i.e. what is the purpose of education (Brown-Martin, 2014).

The debates and issues around technologisation of education have been on the discussion tables of the policy makers as well. European Union has taken up the topic of inclusive education supported through the use of ICT and Open Educational Resources (OER); European Commission's Rethinking Education was published in 2012 primarily addressing necessary changes in education, but also pointing out that "technology offers unprecedented opportunities to improve quality, access and equity in education and training, [since] individuals can learn anywhere, at any time, following flexible and individualised pathways" (European Commission, 2012, 9). Additionally, OER is seen as a great enabler for any level and type of education, thus its potential should be exploited in building up a modern education system that will be inclusive and relevant to the labour market. Apart from using ICT in a more effective way, Rethinking education (2012) also suggests better education of teachers in terms of using the latest technologies in subjects they teach. Published in 2013, Opening up Education followed these trends more closely. The main purpose of the document was to recommend and support actions that will:

1. Help learning institutions, teachers and learners to acquire digital skills and learning methods

2. Support development and availability of open educational resources

3. Connect classrooms and deploy digital devices and content

4. Mobilise all stakeholders (teachers, learners, families, economic and social partners to change the role of digital technologies at educational institutions

The document also serves as a cornerstone in closing the digital divide, especially in terms of equipping the most disadvantaged social groups with access to quality education and learning opportunities.

Despite the optimism that is displayed at the European policy level, the reports such as Education and Training Monitor 2014 reflect a rather negative picture with regards to overall investment in education across the European Member States. Teacher training seems to be a large issue, since it accounts to much of what the education, especially at the general (primary / secondary level) will look like. Most of the recommendations call for a better quality teacher training and education, as well as continuous teacher development. Policies need to be 
set in place and implemented, but more importantly teacher time and motivation is a considerable variable (European Commission, 2014).

Furthermore, much of the literature provides a solid understanding that modern technologies with all its accompanying characteristics offer fertile grounds for learning and teaching. For instance, UNESCO Institute for information Technologies in Education has issued a Policy Brief in 2012 which contextualises education in emergence of ICTs and conceptualises the use of computers in teaching and learning. But potential of ICT in education comes along with great challenges. The brief talks about the changes that are required for the teacher training system as well as for the school management and infrastructure, highlighting that the "mainstream education institutions still largely practice a more traditional approach to education" (UNESCO, 2012, 6). In its recommendations, the 2012 Policy Brief provides a great deal of useful sources and suggestions, ranging from virtual high schools and colleges (such as The Virtual High School and Khan Academy) to learning resources and development ideas for transforming entire classrooms and curricula (such as ISTE).

Although there is much more to be told about the issues and dilemmas of penetration and use of ICT in education, it is at this point most important to stress that introduction of any new kind of technology, as much as it is the case with pedagogical innovations, requires a strong commitment of teachers to change their practice and develop their skills in order to be able to teach the generations of the future.

\section{Imperative to innovate: through schooling, teaching and learning}

It is quite common to learn; people (consciously and unconsciously) do it every day which is why Gert Biesta (2012) argues in favour of returning to the terms educating and teaching as more conscious, directed and purposeful activities through which teachers take command. While his argument stands strongly in support of the teaching professional, it would be uncomfortable to completely agree with Biesta in the current state of educational provisions worldwide. From the perspective of a possible contra-argument teachers today need a different set of skills and knowledge compared to their colleagues from the past simply by a mere fact that they are teaching a different kind of population and preparing them for a different kind of future (OECD, 2009). Thus, it could be argued that only those teachers that are conscious of the responsibility of teaching today and for the future, which has a high requirement of their constant development, could and should take back the control of teaching and educating.

Darling-Hammond (1998) boldly suggested a wide-ranged list of skills that a teacher needs to know, including understanding the subject matter in great depth, having the foundations of pedagogical content knowledge, comprehending child and adolescent development from cognitive, social, physical and emotional aspects, as well as having the capacity to inquire sensitively, with a close look at students' work. According to her, teachers also require knowledge about learning, from different learning types and preferences, to understanding the dynamics of learning among students. In addition, a teacher ought to grasp the value of collaboration and to be adept to analyse and reflect on their own practice. It is important to mention the element of contextual under standing - in every sense, cultural, technological, societal - of both the immediate surroundings and the worlds around. As the European policy document proposes: "[c]onceptualisations of teacher competences are linked with visions of professionalism, theories of teaching and learning, quality cultures and socio-cultural perspectives" (European Commission, 2013, 11-12). Importantly, in Supporting teacher competence development for better learning outcomes a need to understand teacher competences as "dynamic combination of cognitive and 
meta-cognitive skills" is emphasised through assuming four fundamental approaches (European Commission, 2013, 11-12):

- Learning to think as teachers

- Learning to know as teachers

- Learning to feel as teachers

- Learning to act as teachers

The striking common denominator of learning is quite exactly what this article is trying to emphasise and what is sometimes missing in the practice of teaching in the traditional schooling system. Knowledge today is not static which is why it is important to emphasise on teachers who are not only conducting their jobs and performing their "common, traditional" duties, but those who create and who see the duty of learning equally important as the duty of teaching. Ora Kwo (2010) describes this phenomenon with a term teachers as artists and teachers as researchers. It is a new relationship among teachers and educationalists that seeks to re-define and challenge the existing setting, proposing a cross-boundary collaboration and critical discourse and with a moral commitment to education. In her words: "[t]eacher learning involves interpretation of dissonance from latent knowledge and determination to accept complexity of the change process, given that a professional is held accountable for both the existing system and the call for reform" (Kwo, 2010, 318).

Yet, it is not only the teachers that need to change and embrace the paradigm of learning, there is also the need to change education and schooling. A call for rethinking entire systems and levels of education was petitioned by the OECD (2015) in their recent publication Schooling redesigned - towards innovative learning systems. The publication points out towards the necessity of pushing the boundaries and stretching out with regards to innovating the pedagogical core, encouraging learning leadership and opening up for partnership in the wider community. According to this document, there is a need to place a systemic change, and not just isolated innovation, because "[i]nnovating learning environments with collaborative definitions of professionalism and the strong engagement of all partners are also more likely to enhance the attractiveness of teaching than backward-looking definitions" (OECD, 2015, 11).

Thus, the element of the innovative school fits almost naturally and logically within this scientific pursuit, the one that considers teacher learning and shifts in educational paradigms. This is why, here, practices of teachers in innovative environments are considered as the necessary "new normal", as an imperative in order to keep the idea of schooling and education alive for a certain while. Ellis and her colleagues agree that "[i]nnovative teaching practices are often tried in an effort to make one's teaching more effective or to tackle an instructional prob lem or challenge (...) connected to an overall desire to improve students' learning" (Ellis et al., 2011, 4-5). Furthermore, instructional innovations such as cooperative learning techniques have indeed become widespread. Yet they have still not managed to become a common practice in many contexts around the world, despite its strong theoretical background, validation in research and the fact that it has been operationalised into clear procedures for teachers and educators (Johnson et al., 2000). Cooperative learning methods, along with other novel approaches, have shown concrete evidence to produce diverse and positive outcomes for preventing and coping with a spectrum of social issues, such as racism, sexism, exclusion of special needs students, delinquency, drug abuse, bullying and violence, as well as supporting development of self-esteem and a sense of community (Johnson et al., 2000). Additionally, project-based learning has also proven to be helpful especially in deprived contexts and among students with lower socio-economic status, in particular for raising their achievement level to the level of those with high socio-economic status (Halvorsen et al., 2014). 
It is important to stress that new instructional approaches and new pedagogies are certainly an educational must in all of today's social and economic contexts. This "new model of learning partnerships between and among students and teachers, aiming towards deep learning goals and enabled by pervasive digital access", as Fullan and Langworthy (2014) noted, are the only way forward in keeping schools and education from becoming meagre and obsolete.

\section{Conclusions and discussion}

It is a question worthwhile asking for any researcher in the field of education: what is or what has become the purpose of education? According to some, the creation of mass education was built with a specific function - to make pupils sit and listen, develop a specific routine and discipline, so that they could become good factory workers (Seth Godin in Brown-Martin, 2015; Darling-Hammond, 2015). Furthermore, the debate over standardised assessment and the readiness to innovate has become a rather heated one. Hampson and her colleagues have recently compiled a study of 10 cases of 21st schools, and in their introduction, they note that the UK government's goal is to have more students with GCSEs scores from A to C. This brings schools to the model of preparing their students for passing the test better, and not necessarily being any better at things that might matter the most, e.g. to think critically, to be creative and innovative, to be more compassionate and collaborative, etc. Thus, the question that the authors propose is whether this will actually bring a change to the satisfaction of students themselves, parents and teachers. The changing world and the uncertainties that await inevitably push educational practices and goals to change, including the ways of assessment. Brown-Martin (2015) explicitly notes that when teachers get awarded on the base of the league tables, and when their job is restricted with standardised assessment criteria, few dare to try out something new and risk their reputations and sometimes their jobs. In such model, it is of an utmost importance to ask who benefits from the traditional models of education and why are they not modified in a quicker manner.

However, there are changes that push education forward; for example, a commitment from the OECD to understand the best way to measure innovativeness and how it affects schools and reflects on education systems, and just recent announcement in finding ways to assess young people's understanding of global issues and attitudes toward cultural diversity and tolerance, has been a welcoming news. Yet, this does not mean that research could take it easy; more so it only means that topic such as teacher learning in innovative learning environments is a topic worthwhile exploring further.

\section{Szakirodalom}

1. Bakkenes, I., Vermunt, J. D. \& Wubbels, T. (2010). Teacher learning in the context of educational innovation: Learning activities and learning outcomes of experienced teachers. Learning and Instruction, No. 20, 533-548.

2. Beijaard, D., Korthagen, F. \& Verloop, N. (2007). Understanding how teachers learn as a prerequisite for promoting teacher learning, Teachers and Teaching: Theory and Practice, 13:2, 105-108.

3. Biesta, G. (2012). Giving Teaching Back to Education: Responding to the Disappearance of the Teacher. Phenomenology \& Practice, Vol. 6 No. 2, 35-49.

4. Brier, D. (2013). What is Innovation? Obtained May 2016 from: http://www.fastcompany.com/3020950/leadership-now/what-is-innovation

5. Brown-Martin, G. (2015). How the Connected Society is Transforming Learning. Disruptive Media Learning Lab. Obtained June 2016: https://www.youtube.com/watch?v=m15OLAfrRG4

6. Center of Excellence in Leadership of Learning (CELL). (2009). Summary of Research on Project-based 
Learning. Obtained May 2016 from: http://cell.uindy.edu/docs/PBL\%20research\%20summary.pdf

7. Cochran-Smith, M. \& Demers, K. (2010). Research and Teacher Learning: Taking an Inquiry Stance. In Kwo O. (Ed). Teachers as Learners - Critical Discourse on Challenges and Opportunities. CERC Studies in Comparative Education 26.

8. Coffield, F. (2000). The Structure below the Surface: Reassessing the significance of Informal Learning. In Coffield (Ed). The necessity of informal learning. The Policy Press.

9. Darling-Hammond L. (1998). Teacher learning that supports student learning. Educational Leadership, Vol. 55, No. 5.

10. Darling-Hammond, L. (2015). A New Moment in Education. URL: http://www.huffingtonpost.com/linda-darlinghammond/a-new-moment-ineducation_b_8073130.html

11. EdSurge. $21^{\text {st }}$ Century Skills. Obtained May 2016: https://www.edsurge.com/research/edtech-wiki/21stcentury-skills

12. Ellis, D., Bissonnette, C., Furion, S., Hal, Sh., Kenyon, T., McCarville, R., Stubley, G. \& Woudsma, C. (2011). The Task Force on Innovative Teaching Practices to Promote Deep Learning at the University of Waterloo: Final Report. Obtained May 2016: https://uwaterloo.ca/centre-for-teachingexcellence/sites/ca.centre-for-teaching-excellence/files/uploads/files/Task\%20Force\%20Report \%20on\%20Deep\%20Learning_0.pdf

13. Eraut, M. (2007). Learning from other people in the workplace. Oxford Review of Education, Vol. 33, No.4, 403-422.

14. European Commission. (NN). Common European Principles for Teacher Competences and Qualifications. URL: http://www.ateel.org/uploads/EUpolicies/common_eur_principles_en.pdf

15. European Commission. (2012). Communication from the Commission to the European Parliament, the Council, the European Economic and Social Committee of the Regions - Rethinking Education: Investing in skills for better socio-economic outcomes. COM/2012/669 final. Obtained June 2016: http://eur-lex.europa.eu/LexUriServ/LexUriServ.do?uri=COM:2012:0669:FIN:EN:PDF

16. European Commission. (2013). Communication from the Commission to the European Parliament, the Council, the European Economic and Social Committee of the Regions - Opening up Education: Innovative teaching and learning for all through new Technologies and Open Educational Resources. COM/2013/0654 final. Obtained June 2016: http://eur-lex.europa.eu/legal-content/EN/TXT/? uri=CELEX:52013DC0654

17. European Commission. (2014). European ducation, Training and Youth Forum 2014 Report. Obtained June 2016: http://ec.europa.eu/education/events/2014/doc/etyf-report_en.pdf

18. Fullan, M. \& Langworthy, M. (2014). A Rich Seam - How New Pedagogies Find Deep Learning. Pearson. Obtained May 2016 from: http://www.michaelfullan.ca/wpcontent/uploads/2014/01/3897.Rich_Seam_web.pdf

19. Godin, B. (2014). Innovation and Creativity: A Slogan, Nothing but a Slogan. Project on the Intellectual History of Innovation, Working Paper No. 17. Obtained May 2016 from: http://www.csiic.ca/PDF/CreativityEnglish.pdf

20. Godin, B. (2015). Innovation: A Conceptual History of an Anonymous Concept. Project on the Intellectual History of Innovation, Working Paper No. 21. Obtained May 2016 from: http://www.csiic.ca/PDF/WorkingPaper21.pdf

21. Godin, B. (2016). Innovation and Imitation: Why is Imitation not Innovation? Project on the Intellectual History of Innovation, Working Paper No. 25. Obtained May 2016 from: http://www.csiic.ca/wpcontent/uploads/2015/11/Imitation.pdf

22. Government of New Zealand. (NN). New Zealand Education System - Overview. Obtained September 2016 from: http://www.education.govt.nz/assets/Uploads/NZ-Education-System-Overviewpublication-web-format.pdf

23. Halvorsen, A., Duke, N. K., Brugar, K., Block, M., Strachan, S., Berka, M. \& Brown, J. (2014). Narrowing the 
Achievement Gap in Second-Grade Social Studies and Content Area Literacy: The Promise of a ProjectBased Approach. Educational Policy Center. Obtained May 2016 from:

http://education.msu.edu/epc/library/papers/WP26.asp

24. Hampson, M., Patton, A. \& Shanks, L. (NN). 10 schools for the $21^{\text {st }}$ century. Innovation Unit. Obtained June 2016: http://www.innovationunit.org/sites/default/files/10\%20Schools\%20for\%20the\%2021st \%20Century_0.pdf

25. InnoveEdu. Tendencies that inspire. Obtained May 2016:

http://www.innoveedu.org/trends\#personalizacao

26. Illeris, K. (2009). A comprehensive understanding of human learning. In Illeris K. (Ed). Contemporary Theories of Learning - Learning theorists ... in their own words. Routledge Taylor and Francis Group: London and New York.

27. Illeris, K. (2015). The Development of a Comprehensive and Coherent Theory of Learning. European Journal of Education, Vol. 50, No. 1.

28. Jarvis, P. (2009). Learning to be a person in society: learning to be me. In Illeris K. (Ed). Contemporary Theories of Learning - Learning theorists ... in their own words. Routledge Taylor and Francis Group: London and New York.

29. Kozma, R. B. (1985). A Grounded Theory of Instructional Innovation in Higher Education. The Journal of Higher Education, Vol. 56, No. 3

30. Kwo, O. (2010). Teachers as Learners: A Moral Commitment. In Kwo O. (Ed). Teachers as Learners Critical Discourse on Challenges and Opportunities. CERC Studies in Comparative Education 26

31. Mergendoller, J. R. \& Thomas, J. W. (NN). Managing Project Based Learning: Principles from the Field. Obtained May 2016 from: http://bie.org/images/uploads/general/f6d0b4a5d9e37c0e0317acb7942d27b0.pdf

32. Lave, J. \& Wenger, E. (1991). Situated Learning - Legitimate Peripheral Participation. Cambridge University Press.

33. O'Sullivan, D. (2008). Defining Innovation. Obtained May 2016 from: https://www.scribd.com/doc/283731003/Defining-innovation-O-Sullivan-2008

34. O'Sullivan, D. (2007). Applied Innovation. Technlink. Obtained May 2016 from: http://qi.idit.up.pt/uploads/qi_projdocs19.pdf

35. Rogers, E. (2004). Diffusion of Innovations presentation upon receiving the Converse Award for Marketing at University of Illinois at Urbana-Champaign, April 30, 2004. Video by Ken Schreiner. Obtained May 2016 from: https://www.youtube.com/watch?v=jluc7yZH6eU

36. Schön, D. (1983). The Reflective Practitioner - How professionals think in action. Basic Books, Inc.

37. UNESCO. (2012). Policy Brief - ICTs for curriculum change. Obtained June 2016: http://iite.unesco.org/pics/publications/en/files/3214717.pdf

38. UNESCO. (2015). Rethinking Education: Towards a Global Common Good? UNESCO Publishing 